Journal of History Culture and Art Research

Revue des Recherches en Histoire Culture et Art

مجلة البحوث التاريخية و الثقافية و الفنبة
Vol. 4, No. 2, June 2015

Copyright (C) Karabuk University

http://kutaksam.karabuk.edu.tr/index.php

\title{
DOI: 10.7596/taksad.v4i2.421
}

\section{Detective Stories from Sherlock Holmes to Whitechapel ${ }^{1}$}

\section{Feryal Çubukcu²}

\section{Abstract}

The Victorian period in England was one of the most influential and important epochs in history. During Queen Victoria's reign, England was arguably the most powerful nation in the world, setting standards for social, economic and industrial development. Among the rules of Victorian society were stringent codes pertaining to what was acceptable for men and women. Men were expected to hold decent jobs, marry respectable women, and create the next generation of proper British citizens. Women were raised to marry, breed virtuous English children, and live quietly in the confines of the household. As Elaine Showalter (1987) says Victorian households had different spheres for men and women. There were certain behavioral norms for men and women that were standard practice for asserting one's proper gender codes. In his 1995 book Victorian Masculinities, Herbert Sussman identifies, within Victorian men's writing, a method of constructing masculinity that opposes the dominant English model of manliness based on bourgeois domestic matrimony. During the first half of the Victorian period, normative masculinity required a man to master his psychic energy by establishing a bourgeois domestic identity founded on matrimony. However, this concept translates into the bachelordom plot, wherein male desire finds an appropriate outlet in a sidekick rather than a wife, thus, under the terms of popular middle-class belief, permanently affirming masculinity. When we come to 2010s a bestseller Whitechapel hinges on the same lone detective trying to pursue the killers and criminals. The purpose of this paper is to probe and grapple with the similarities and dissimilarities the detective genre from Sherlock Holmes to Whitechapel by focusing on the detective himself, the crime types, criminals- their motives and ethnic origins-, masculinity, and male-male bonding.

Keywords: Detective genre, Masculinity, Sherlock Holmes, Whitechapel.

\footnotetext{
${ }^{1}$ This paper was presented in the 2nd English Studies Conference which was held between 8-10 May 2015 in Karabuk University.

${ }^{2}$ Dokuz Eylül University, cubukcu.feryal@gmail.com,
} 
The Victorian period in England was one of the most influential and important epochs in history. During Queen Victoria’s reign, England was arguably the most powerful nation in the world, setting standards for social, economic and industrial development. Among the rules of Victorian society were stringent codes pertaining to what was acceptable for men and women. Men were expected to hold decent jobs, marry respectable women, and create the next generation of proper British citizens. Women were raised to marry, breed virtuous English children, and live quietly in the confines of the household. As Elaine Showalter (1987) says Victorian households had different spheres for men and women. There were certain behavioral norms for men and women that were standard practice for asserting one's proper gender codes. In his 1995 book Victorian Masculinities, Herbert Sussman identifies, within Victorian men's writing, a method of constructing masculinity that opposes the dominant English model of manliness based on bourgeois domestic matrimony. During the first half of the Victorian period, normative masculinity required a man to master his psychic energy by establishing a bourgeois domestic identity founded on matrimony. However, this concept translates into the bachelordom plot, wherein male desire finds an appropriate outlet in a sidekick rather than a wife, thus, under the terms of popular middle-class belief, permanently affirming masculinity. When we come to 2010s a bestseller Whitechapel hinges on the same lone detective trying to pursue the killers and criminals. The purpose of this paper is to probe and grapple with the similarities and dissimilarities the detective genre from Sherlock Holmes to Whitechapel by focusing on the detective himself, the crime types, criminals- their motives and ethnic origins-, masculinity, and male-male bonding.

Sussman's alternative masculine plot centres on the removal of the male protagonist from female influence in order to construct a masculinity untainted by the feminized domestic work, the plot structure of the adventure novel, with its journey away from home and its quest for identity. In this alternative narrative of masculine identity, the hero, seeking an exclusively male universe, leaves the feminine domestic sphere and avoids a course progressing towards marriage. Instead, he endures a series of tests of masculinity, gathering male wisdom from father figures along the way, his journey culminating with a manhood marked by chaste malemale bonds. This paper aims at tackling some Sherlock Holmes stories in terms of the Victorian masculinity of which features are delineated by Sussman and tries to justify that the masculine tests endured by Sherlock Holmes usually involves the rejection of the female or mother, often figured by the casting off of female influence, and bonding with the father or more often surrogate father, which is, in this case, Dr. Watson, an act sealed by chaste bodily contact within carefully controlled rituals of male-male physicality. Closure comes, writes 
Sussman, with the sublimation of dangerous male desire into productive work and initiation into a male community rather than with joining in marriage.

Cawelti (1976) explains that Poe's 'Murdersin the Rue Morgue' established all the necessary components for the form of mystery story he calls the classical detective story. The classical detective, here Holmes, works by ratiocination, rationalization (logic) and solves the mystery with his intellect. The plots of such stories use six main phases:
(a) introduction of the detective;
(b) crime and clues;
(c) investigation;
(d) announcement and solution;
(e) explanation of the solution;
(f) denouement.

These parts do not always appear in sequence and are sometimes collapsed into each other, but it is difficult to conceive of a classical story without them. $(81-82)$. This narrative strategy reveals each of the story's key points. Cawelti suggests that classical detective stories play on specific desires in the reader. They "aestheticize”" crime, making a chaotic moment into an artistic puzzle. They also attribute crimes to individuals, an important psychic salve for middle-class readers concerned with the rising rate of crime in urban centers (98 - 104). Classical detective stories reinforce the notions of individual responsibility, rational thought, and crime. They eschew social explanations for crimes in favor of individual ones.

The detective is called in to investigate a seemingly simple thing, like a disappearance; his investigation comes up against a web of conspiracy that reflects the presence of a hidden criminal organization; finally, the track leads back to the rich and respectable levels of society and exposes the corrupt relationship between the pillars of the community and the criminal underground (148 - 49). Narratives that show such a profound distrust of cultural institutions give a different motivation for individual action to their protagonists.

Where classical detectives operate in a detached, scientific way, and also investigate because they care about their clients; "the hard-boiled detective is a traditional man of virtue in an amoral and corrupt world', (152). Hard-boiled detective stories still provide recourse to individual action, but they do so in a context where the detective's virtue (along with quick wits and righteousness) might be the only card he holds (909-910).

The classical detective could work with the police and government. But like his classical counterpart, the hard-boiled detective still reinforces the ideals of individual action 
and responsibility. Both classical and hard-boiled detective stories function as narrative allegories for the act of rational thought in the literate age.

Doyle seems to construct three categories of contamination into Victorian society, all of which are represented as posing significant threats to the nation, which are all male oriented:

-British characters who are portrayed as having become morally bankrupt, corrupt, and greedy as a result of their time in the colonies;

-British characters who have become physically deformed or financially ruined during their colonial ventures; and

-Lastly people and things originating in the colonies, such as a poisoned-dart-throwing cannibal and a mysterious hysteria-inducing powder, that travel to the colonial center and threaten its wellbeing.

Doyle's colonial others serve to justify Britain's imperial expansion by conjuring images of Anglo cultural superiority, but also express anxiety about the supposed danger surrounding contact with non-Western cultures. This corrupt foreign land effect is visible in most of Doyle's stories. Despite this anxiety, inextricably linked with the Indian Rebellion of 1857, Doyle reassures his audience that in the end, Britain can prevail thanks to Sherlock (Raheja, 2006:417).

Grimesby Roylott (The Adventure of the Speckled Band) and Leon Sterndale (The Adventure of the Devil's Foot) are characters who return home to Britain after venturing into India or West Africa as doctors. After Grimesby Roylott has returned to Britain, it becomes clear that he had undergone frightening transformations during his stay in Calcutta, according to his stepdaughter, Helen Stoner. A “terrible change” came over him, Miss Stoner explains to Holmes and Watson:

He shut himself up in his house and seldom came out save to indulge in ferocious quarrels with whoever might cross his path. Violence of temper approaching to mania had been hereditary in the men of the family, and in my stepfather's case it had, I believe, been intensified by his long residence in the tropics (Doyle, 2003: 310).

Thaddeus Sholto of The Sign of Four and Henry Wood of The Crooked Man are two examples of characters who become physically repulsive, pathetic men as a result of their contact with foreign lands. 
In The Sign of Four, opium is a symbol of the contamination that comes from Eastern colonies, and Thaddeus Sholto is the victim of that contamination. Like other characters that appear in the Holmes canon, Thaddeus is depicted as having become a physically and mentally weaker person, lacking self-control and discipline. The contrast between Holmes's domination of the cocaine that he injects into his veins and Sholto's resignation to his opium addiction provides justification for the colonial rule. Both cocaine and opium, emanating from India, China, and South America, represent foreign lands, and Thaddeus's weakness serves as a warning of the threat that the East may pose to the West. Holmes's control of his cocaine use provides reassurance that the West is capable of bringing the East under its control, and that it must do so (Raheja, 2006:421).

There were a number of different forms of masculinity evident in Victorian Britain and there was quite as strong a sense of not quite meeting the dominant masculine norms amongst even very successful men in the mid nineteenth century as there was at its end-and this was clearly the case in a number of what one might refer to as the central Bloomsbury families (Caine, 2007:272).

In Victorian Masculinities, Herbert Sussman (1995) effectively summarizes the complexity of the issue of masculinity. His study is based on the notion that masculinity is a historical construction rather than an essentialist given. He demonstrates how each artist and writer shapes the possibilities of manliness available to him within his cultural moment into a very personal configuration that necessarily participates within the more general discourse of the masculine.

"Manhood" is the behavioral state of rigorously controlled and disciplined manliness achieved (but not necessarily continuously maintained) by the Victorian bourgeoisie through “arduous public and private ritual” (Sussman, 1995:13). “Manliness” refers to contemporary social constructs, and "masculine poetics" similarly signifies a construction, as opposed to an essentialist idea of "male poetics" or related fantasies of "maleness."

Manliness is concerned with containment of what was perceived as potentially destructive energy inherent in men, a kind of outwardly controlled stasis as defined in the early Victorian period. These distinctions are important and are precisely stated in the introduction. In fact, his book deals with the concept of masculinities in the nineteenth century, in terms of the implication of multiple forms of the masculine in the period, continuously marked by instability and fluidity. There is no one definition, and the implied opposition to femininities is here conceived not as a binary relationship (as it has been in much recent scholarship), but more productively as one in which the various slippages of 
meaning, definition, and representation of the two terms are more evocatively expressed. Sussman (1995) writes that “applying such typologies of Victorian manliness ['gentleman,' 'prophet-sage,' ‘professional man'] to artists and writers productively complicates the pervasive academic model that situates nineteenth-century gender conflicts solely within the binary of masculine/feminine” (14). The results of this productive complication are formations that challenge the normative definitions of manliness in Britain.

Doyle's Sherlock Holmes is the embodiment of a gentleman, a prophet and a professional:

Few men were capable of greater muscular effort, and he was undoubtedly one of the finest boxers of his weight that I have ever seen; but he looked upon aimless bodily exertion as a waste of energy, and he seldom bestirred himself save when there was some professional object to be served. Then he was absolutely untiring and indefatigable. That he should have kept himself in training under such circumstances is remarkable, but his diet was usually of the sparest, and his habits were simple to the verge of austerity. Save for the occasional use of cocaine, he had no vices, and he only turned to the drug as a protest against the monotony of existence when cases were scanty and the papers uninteresting (Doyle, 2003: 295).

Even at first glance Holmes easily deduces that Watson is not feeling well. "Your slippers are new," he said. "You could not have had them more than a few weeks. The soles which you are at this moment presenting tome are slightly scorched. For a moment I thought they might have got wet and been burned in the drying” (295). But near the instep there is a small circular wafer of paper with the shopman's hieroglyphics upon it. Damp would have removed this. Watson had, then, been sitting with his feet outstretched to the fire, which a man would hardly do even in so wet a June as this if he were in his full health.

Apart from encompassing the roles of a gentleman, prophet and professional, the other characteristic of masculinity in that era is shown in A Man's Place: Masculinity and the Middle-Class Home in Victorian England. John Tosh (1999:4) explains that "the domestic sphere is integral to masculinity.” According to Tosh, a gentleman was expected to marry and produce an heir to his name because single men, who were not able to vote and did not pay taxes, never enjoyed the level of societal respect given to married gentlemen. Establishing a home, protecting it and one's family, providing for and controlling it, had long been essential to a man's "good standing with his peers.” The Victorian cult of domesticity, most often 
associated with women, also meant that, for men, home was a place of greater importance than before. In the latter half of the century, however, domesticity began to change from being an extension of the Victorian gentleman's imperial, public persona to a space where privacy and comfort, separation from the workplace, and the merging of domestic space and family members created a single commanding concept home. Such domestic roles are missing in Sherlock. However, we witness his older brother Mycroft in The Greek Interpreter when he mentions that possessing deductive powers exceeding even those of his younger brother, Mycroft is nevertheless incapable of performing detective work similar to that of Sherlock as he is unwilling to put in the physical effort necessary to bring cases to their conclusions. He has no ambition and no energy. He will not even go out of his way to verify his own solutions, and would rather be considered wrong than take the trouble to prove himself right. When Sherlock Holmes has taken a problem to him received an explanation which has afterwards proved to be the correct one.

The political, economic and technological changes that Britain had experienced in the eighteenth and nineteenth centuries had resulted in the reconstruction and institutionalisation of social relationships; differences between men and women, already a topic of interest, were further emphasised in the medical literature of the day and through the establishment of specific roles in domestic ideology. This division of the sexes found its way into virtually all aspects of music. Musical pieces, genres, composers, performers and instruments were frequently divided along 'masculine’ and ‘feminine' lines. Even music-related activities were gendered. Composing, conducting, critiquing and theorizing were 'masculine' because they required sustained mental effort, which, according to popular belief, could handicap the reproductive capabilities of women. Performing was 'feminine' or 'masculine' depending on where it was being done (public/private space) and who was performing, as if these divisions were not enough, music as a whole was considered to be a 'feminine' art (Yuen, 2005:83).

A major one was tradition; for centuries in Britain, men believed that playing music led to feminisation, and so must be avoided at all costs. Also largely responsible was the development of a masculine ideal in Victorian Britain whereby a man was expected to be disciplined, industrious and responsible; such an ideal man could hardly have time to pursue leisurely and frivolous pursuits like music (Leppert, 1988: 22). Even if a man did pursue music as a profession, he had to be a recognized genius or expert, or had to be highly proficient in other areas of life. Music, an integral part of Holmes's life shows its reverberation in his playing the violin in stark difficult circumstances. 
Knight (1980) argues that Holmes serves a specific masculinizing agenda, masculine, delicate, scientific, the ideas go together to state them a le self-concept, the delicate frailty it perceives in itself, and the protection it finds in a scientific hero, it is easy to witness his rejection of the female and bonding with the father or more often surrogate father, which is, in this case, Dr. Watson, an act sealed by chaste bodily contact within carefully controlled rituals of male-male physicality. He then comments on the tales in Adventures in the early stories there are two distinct, but related, patterns of masculine fear. One is the fear of castration, directly losing potency. The other is fear of being supplanted, losing control over a daughter or a wife (377).

In the opening of The Red-Headed League, Holmes declares:

I know, my dear Watson, that you share my love of all that is bizarre and outside the conventions and humdrum routine of every-day life. You have shown your relish for it by the enthusiasm which has prompted you to chronicle, and, if you will excuse my saying so, somewhat to embellish so many of my own little adventures (49).

What makes Watson as a surrogate mother/lover to Holmes is his concentration throughout the Holmes canon on wounded or disabled men, a marker of castration anxiety in scribing deep cultural doubt about masculine superiority and power. This psychological rebus is noted at the very beginning of the Holmes tales with the details of John $\mathrm{H}$. Watson's being wounded at the disastrous battle of Maiwand in the Afghan campaign, on July 27, 1880. In the second paragraph of A Study in Scarlet, Watson comments: "I was [...] attached to the Berkshires, with whom I served at the fatal battle of Maiwand. There I was struck on the shoulder by a Jezail bullet" (5). In The Sign of the Four, the narrative commences by reference to a wound: "I [...] sat nursing my wounded leg. I had a Jezail bullet through it sometime before" (5). In “The Noble Bachelor,” from the Adventures, Watson records:

I had remained indoors all day, for the weather had taken a sudden turn to rain, and the Jezail bullet which I had brought back in one of my limbs as a relic of my Afghan campaign, throbbed with dull persistency (221).

Conflicted male sexuality is implicitly shown in the first tale of the Adventures, "A Scandal in Bohemia," shows Holmes being defeated by a woman, Irene Adler, who "has the face of the most beautiful of women, and the mind of the most resolute of men" (p.14). She follows 
Holmes to 22IbBaker Street in order to alert him that she knows of his stratagems. She dresses herself in male attire: "Male costume is nothing new to me. I often take advantage of the freedom which it gives" (28). Not only is Holmes defeated, but the manifestation of this defeat is the woman's transgressive act of cross-dressing (Kestner, 1996).

The series, Whitechapel, is a very modern take on the detective genre which combines the Victorian intrigue of the original case with the atmospheric backdrop of a contemporary East End of London. The first series is not only simply about bloodthirstily recreating the murders of Jack the Ripper, but also focusing on the three main characters at the heart of the story especially DI Chandler and the black humour that binds the team together.

Although it is easy to label the series (2009-2013) as formulaic (the young fasttracked, techno savvy DI Chandler and the middle aged experienced Detective sergeant Miles) and unresembling Holmes and Dr. Watson, Whitechapel creators Ben Court and Caroline Ip might argue that it is more of a recipe: there are certain ingredients that can be reused to make a repeatable but distinctive show. One of them is pitch-black humour. There's a running gag about Chandler and his squad being incapable of bringing a guilty party in alive. The second is the bond between the male detectives. The series Whitechapel taking its name from the district where Jack the ripper committed his crimes has been recast as a place with an in-built conveyer-belt of baddies happening to live in the same popular Victorian district. Thirdly, there is still a sense of xenophobia. When Chandler gets the note from the killer, he declares that the handwriting must be Eastern European-what a talent!-because he’s “done a lot of courses.” Miles gives him a "you're a weirdo” look but for once, Chandler's formal schooling comes in handy and makes up for his lack of street experience. After talking to the owner of the company with the van in which Mary was killed, detectives get the name of the driver for the night in question: Anthony Pricha, who works in the morgue at the hospital. He gets hauled in for an interrogation but says he neither works for the company nor drives a van. It turns out someone stole his identity. Chandler's suspecting of an Eastern European migrant does not show any difference from Holmes’ stories.

Holmes' shying away from the domesticity and women is not visible in Chandler's private life. He is a single father, too busy to date women but he finds time to sleep with a babysitter and then a psychologist. He is depicted as an ambitious young cop on the career path to a plush administrative position, once he puts in some time in an actual squad room. He does not make a winning impression on the rough-and-tumble cops when he makes his debut at the police station wearing black tie to lead the investigation into the death of a young woman found in Whitechapel. In addition to being a neat freak whose response to pressure is 
to rub Tiger Balm on his temples, Chandler initially shows nothing but disdain for the disheveled, under-motivated staff, especially Detective Sergeant Miles, which marks him as distinct from Holmes.

To sum up, it is easy to claim that masculinity can be defined by both its presence - as agents perform normative constructions of masculine subjectivity - and its apparent absence at sites such as the terminally sick body or in some of the performances and practices of the art of music. Perceived as powerful yet asexual, Holmes manages to assert his masculinity as a boxer, as a violinist, as a prophet, as a detective (Professional) and as a friend. In the similar vein, Chandler is depicted as wedded to his profession, mouthy, fast thinking, and powerful yet asexual. From the Victorian era up to now, it is easy to see the commonalities in the detective genre where the main character is a sleuth: very smart, charismatic, extremely complicated, articulate, well-schooled, well-bred, astonishingly athletic, exceptionally brawny, elegantly dressed, masculine without having any love affairs, solitary figures leading a sequestered life, in short a character with the plurality of masculinities.

\section{References}

Caine, Barbara (2007). Bloomsbury Masculinity and Its Victorian Antecedents The Journal of Men's Studies, 15, 3, 271-281.

Cawelti, John G. (1976). Adventure, Mystery, and Romance: Formula Stories as Artand Popular Culture. Chicago: University of Chicago Press.

Doyle, Arthur Conan. (2003). The Complete Sherlock Holmes. Vol. I. New York: Barnes \& Noble Classics. The Adventure of the Devil's Foot, 461-79; The Adventure of the Speckled Band, 307-25. The Crooked Man, 491-503; The Sign of Four, 97-184. London: Wildside Press.

Kestner, Joseph (1996). Real men: Construction of masculinity in Sherlock Holmes Narratives, Studies in the Literary Imagination 29, 1, 73-88.

Knight, Stephen (1980). Form and Ideology in Crime Fiction. Bloomington: Indiana UP. Leppert, Richard (1988). Music and Image: Domesticity, Ideology and Socio-Cultural Formation in Eighteenth-Century England. Cambridge: Cambridge University Press. 
Raheja, Lauren (2006). Anxieties of Empire in Doyle's Tales of Sherlock Holmes, Nature, Society, and Thought, 19, 4, 417-426.

Riley, Brendan (2009). From Sherlock to angel. The Journal of Popular Culture, 42, 5, 908922.

Showalter, Elaine (1987). The Female malady. London: Penguin Books.

Sussman, Herbert (1995). Victorian Masculinities. Cambridge: CUP.

Tosh, John (1999). A Man's Place: Masculinity and the Middle-Class Home in Victorian England. New Haven: Yale University Press.

Yuen, Karen (2008). Bound By Sound: Music, Victorian Masculinity and Dante Gabriel Rossetti. Critical Survey, 20, 3, 79-96. 